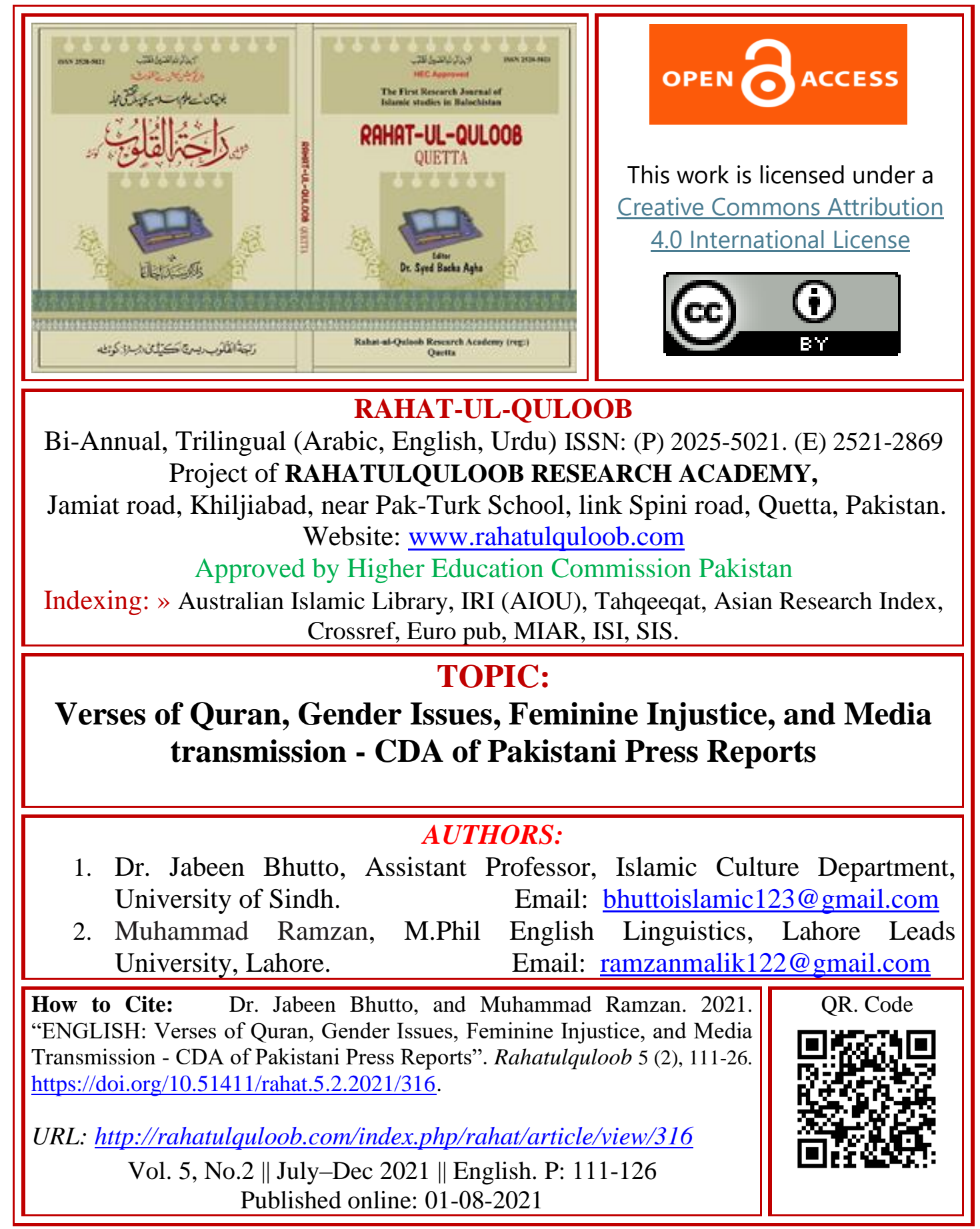




\title{
Verses of Quran, Gender Issues, Feminine Injustice, and Media transmission - CDA of Pakistani Press Reports
}

\author{
${ }^{1}$ Jabeen Bhutto, ${ }^{2}$ Muhammad Ramzan
}

\section{ABSTRACT:}

Pakistan is an Islamic country and has been established in the name of Islamic ideology but rape and murder of innocent children and ladies, like Zainab presents a very ugly and obnoxious image of this Muslim nation. This research has been done to find the gender issues and feminine injustice in Pakistani press news reports from Critical Discourse Analysis viewpoint in light of teachings of Quran. It is said in the

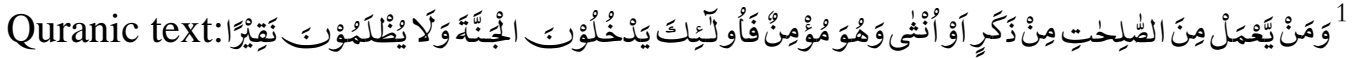
"And whoso doeth good works, whether of male or female, and he (or she) is a believer, such will enter paradise and they will not be wronged the dint in a date-stone". This research study is done to explain, what Quran says about gender issues and women injustice, using out press statements, images, and columns taking from both in English and Urdu languages newspapers, namely the Dawn and Express. The statements are taken during the week, after happening of brutal episode i.e. from 8 January 2018 to 14 January 2018. Inspiration of this project is created in the background of Zainab's sexual abuse and gruesome rape, which happened in first week of January 2018. Initially the teachings of Quran, gender issues, feminine injustice and media discourse are explained briefly because injustice with ladies and children have been growing very rapidly since previous two decades in Pakistan. Then the significance of research is highlighted. This research is carried out in the paradigm of qualitative approach. Non probability purposive sampling technique is adopted for sample selection from selected newspapers. Van Dijk ${ }^{2}$ CDA model has been implemented for data analysis of the research, but keeping in view the hypothesis of the study the selected points are discussed only. The essential aim of the research is to focus on the pacifier and collusive stance of media, wrapped in the agenda of power which has been explored through Van Dijk ${ }^{2}$ CDA model.

Key Words: Gender Issues, Feminine Injustice, Rape, Sexual Abuse, Ideology, CDA, Press Reports.

\section{Introduction:}

In the literal words, gender issues and feminine injustice are related to the harsh, offensive, and exploited treatment of men over the women and it is known as impediment for the accomplishment, harmony, peace and prosperity in every society. The gender issues are associated with discrimination and maltreatment of women around the world. These issues either develop asymmetric associations in professional participation of feministic strata along with men or promote the psychological disassociations among women in the society. In the ayat of Surat un-Nisa Allah has 
said that: The forgiveness is not for those who do ill-deeds until, when death attended upon one of them, he saith: Lo! I repent now; nor yet for those who die while they are disbelievers. For such we have prepared a painful doom ${ }^{1}$ In the world, more than half of the population is consisted on women and among them; majority is under the influence of discrimination due to gender issues and feminine injustice although it exists few variants there in every religion, culture and society. ${ }^{3}$ But Allah Almighty has said regarding gender issues and feminine injustice in the ayat of Surat AtTawabah (Repentance) that: The believers, both men and women, are allies of one another. They enjoin good, forbid evil, establish Prayer, pay Zakah, and obey Allah and His Messenger. Surely Allah will show mercy to them. Allah is All-Mighty, AllWise. ${ }^{4}$ Many religions, communities and countries are being inflicted by the gender issues and feminine injustice in the world and it has been worsened by the science and technological development because the sex of fetus can be predicted in womb before the arrival of baby in this world after nine months. In 1978 and 1983 at Mumbai, there were aborted seventy-eight thousand fetuses because they had been recognized as female fetus ${ }^{5}$. Similarly, it is also reported by different researchers that gender issues and feminine injustice are very common around the world. ${ }^{3}$ But Allah has said in the wording of Quranic verse 34 of Surat An-Nisa Ayat that"Men are the protectors and maintainers of women, because Allah has given the one more (strength) than the other, and because they support them from their means" .The gender is known as a basic marker of social stratification and gender issues are associated with feminism, because women are not just only victimized by social injustice, but also deprived from the fundamental rights in Pakistan, as well as in the world. Similarly, it is observed that in spite of significant improvements based on economic development, women still lag behind men in their degree of labor and market participation at many places in the world. Gender is generally a broad term and social roles, attitudes, activities and features for the men and women stand under this umbrella term. But in many societies, cultures and civilizations, the ladies are victimized by the violence physically, sexually, economically and psychologically, without regarding the race, class, nationality and age. Gender issues and feminine injustice are very old fact, which are prevailing since the birth of man because women are not independent in their own homes at all stages of age because in childhood she is dominated by father, in youth by her husband, after the death of her husband by her son. Similarly in present era, gender issues and feminine injustice are very common across the world, e.g., renunciation in equality, human rights, and suppression, but the cultural, religious and traditional values affect them in different ways. Although gender issues and feminine injustice have many faces, but common to the entire world are early marriages, sexual harassment, domestic violence, female infanticides, female feticides, denial of education, discrimination in basic human rights, divorce, domestic violence, dowry, destitution, low respect, minimum authority in families/society, sexual rape and abuse. In 1993, United Nation General Assembly defined gender-based violence, as any harmfulness of ladies physically, 
sexually and psychologically. It is further noted that patriarchal structure subjugates women and causes violence against them. ${ }^{6}$ It was appearance of power abuse against gender issues and feminine injustice which influenced all over the world, generally the developed countries and nations as well as under developed part of the world. This also became the cause of discrimination of men over women at the one end and domination at the other side.

The violence on gender-based issues has become the main restriction in achievement of women and girls human rights ${ }^{6}$. Similarly, the aspirations in this paper come from the incident of brutal murder and savage rape of innocent six-year-old girl, Zainab, in January 2018, belonging to district Kasoor, a living example of gender issue and feminine injustice in Pakistan. Patowary $\mathrm{H}$. says that for the progress and prosperity of ladies, it is very vital the availability of suitable circumstances, where they can approach against the social discrimination and gap between genders which they are facing and undergoing in patriarchal and male dominated society ${ }^{7}$. The development in the status of women from every viewpoint is the way to wipe out gender discrimination and feminine injustice and will also provide the opportunities of secured and comfortable life among female strata. For the sake of such values, communication is a fundamental tool and furthermore social customs, manners, behaviors, attitudes and standards are framed through mass media. It is known fact that the role of media is powerful and significant in stimulating and broadcasting these reports in communities and it is also one of fundamentals in social, educational, economic and political prosperity of the ladies. Therefore, gender issues also stand under the mercy of media and in this sense language play very crucial role. As James Paul Gee says that language is capable of saying, doing and being and it not only constructs and reconstructs the actions and buildings in the world, but also social phenomenon is regularly built and rebuild in the language, like tools, objects, nonlinguistic symbols and technologies ${ }^{8}$. This research is purely qualitative based; taking the sample from two widely read newspapers, i.e., the Express (Urdu) and the Dawn (English) and analysis shows that there is collusive and pacifier stance between print media and powerful people (Journalists and Politicians) for the exploitation of Islamic Ideology.

\section{Literature Review:}

The main focus in this part is towards verses of Quran and theories which are related to the gender issues, or connected with feminine injustice and tasks performed by media in reporting such episodes. Allah has said in Surah Noor Ayat 1\&2, that "The female and male fornicator - lash each one of them a hundred lashes, and let not pity for them take you within the religion [i.e., law] of Allāh, if you should believe in Allāh and the Last Day. And let a group of the believers witness their punishment. The fornicator does not marry except a [female] fornicator or polytheist, and none marries her except a fornicator [or adulterer] or a polytheist). And that has been made unlawful to the believers"9. In Surah Ghafir (The Forgiver) the $40^{\text {th }}$ verse Allah Almighty states that "He that works evil will not be requited but by the like thereof: 
and he that works a righteous deed - whether man or woman - and is a Believer- such will enter the Garden (of Bliss): Therein will they have abundance without measure"10. Islam has allotted the inheritance share to the female whether she is a daughter, a mother, a wife or a sister. It is depended on the degree of individual relationship to the deceased and inheritors' numbers. She will be given certain share from the property of deceased. Surat An-Nisa Verses number 11, 12,176 it is said that "Allah (thus) directs you as regards your children's (inheritance): to the male, a portion equal to that of two females: if only daughters, two or more, their share is two-thirds of the inheritance; if only one, her share is a half". Similarly, Allah says that "In what your wives leave, your share is a half, if they leave no child; but if they leave a child, ye get a fourth; after payment of legacies and debts. In what ye leave, their share is a fourth, if ye leave no child; but if ye leave a child, they get an eighth; after payment of legacies and debts". Allah further says that "They ask thee for a legal decision. Say: Allah directs (thus) about those who leave no descendants or ascendants as heirs. If it is a man that dies, leaving a sister but no child, she shall have half the inheritance: if (such a deceased was) a woman, who left no child, her brother takes her inheritance: if there are two sisters, they shall have two-thirds of the inheritance (between them): if there are brothers and sisters, (they share), the male having twice the share of the female. Thus, doth Allah make clear to you (His law), lest ye err. And Allah hath knowledge of all things". ${ }^{1}$ Discourse Analysis is the study of language in use. ${ }^{8}{ }^{11}$ In addition to this van Dijk says that CDA stands under the umbrella of discourse analytical research which studies the routes for the creation of social power abuse, dominance, and inequality. It also views how discrimination, abuse of power and domination are produced and reproduced in the language. ${ }^{12} \mathrm{CDA}$ is an important module of the media and it investigates either the social, historical and political contextual impacts, or structured power issues in the present discursive area. ${ }^{13}$ Language is a neutral phenomenon and is neither a property of sender nor receiver, but is known as a shared culture- space. The production of meanings also takes place through language. ${ }^{14}$ There is hardly any delimited agenda in CDA paradigm and it is a vast theoretical body of the knowledge which is used for the research in the domain of social science and language is a one of them because Foucault conceived discourse as a social structure and discursive practice as a social practice. CDA tries to find out the moral issues in the use of language simultaneously it is concerned with minute and encyclopedic illumination in the discourse. ${ }^{15} \mathrm{CDA}$ also exposes the hidden and delicate ideological stance created by the privileged over the less powerful people in the text as well as under the text .In addition to this Fairclogh says about language that it is a part of society and all linguistic phenomena are social, but all social phenomena in part are linguistics. ${ }^{16} \mathrm{Van}$ Dijk (1998) describes CDA as a tool for the evaluation of domination, hegemony and power in the discourse. Power and ideologies are entailed always in discourse analysis and these tools are intermingled in past and present context. It is observed that different people interpret discourse differently because hegemony, social status and knowledge 
always exist different among different people. The exact explanation cannot be drawn in discourse analysis. ${ }^{17}$ Hallidays's Systematic Functional Grammar throws light on the significance of the language because it is a source for the enactment of various meanings. Halliday further emphasizes on the choice for making meanings in systematic pattern of language and he says that human language has three meta functions and also is endowed to describes three kinds of meanings, 1 ; Ideational is concerned with the transference of semiotic content from speaker to hearer,2; Inter-personal is known for the use of language to manage and influence the relationships between speaker and hearer, and 3;Textual meanings of the language constructs the relationships between the different forms of the text. ${ }^{18}$ Van Dijk speculates that underlying ideologies are displayed in the discourse by using the resource of lexis. According to him the lexical choice is never unbiased and it can increase or decrease the intensity for conveying meanings. Furthermore, references can also denote various degrees of speakers' intentions, positions \& emotions. ${ }^{19}$ Tolon expresses the significance for the choice of lexemes in media discourse that journalists have rich inventories of overlapping descriptors to choose from as they sort out which characterization fits their (ideologically contextualized) account of things best. The individuals, groups, their characteristics and actions are attributed towards specific lexical choices and these lexical options not only differentiate between the peoples and their qualities but also their actions are represented and determined with the help of these lexical choices. ${ }^{20}$ The preliminary study of media profile and role of gender was carried out by Courtney and Lockeretz in advertisements analysis and findings suggested that stereotyped gender role was very common in advertising. ${ }^{21}$ Females characters were described less knowledgeable and in the possession of low technical expertise then male members. ${ }^{22}$ In United States and Europe, massive researches have been done in gender studies during last thirty years, but opposite to this in Asia, gender portrayal studies were comparatively low. Recently with the passage of time, the genders studies have penetrated their roots around the world, although in Asia female were described differently in the media. Female stereotypes studies were also drawn in the Asian culture as female in Asia are seen busy in the tasks, like cleaning and household maintenance, as compared to American female strata. ${ }^{23}$ American ladies experience minor discrimination and inequality. Generally, it is believed that difference is seen due to the Confucianism, Buddhism, and traditional bias towards the role of gender. The identity of the female strata is ambiguous in South Asia, as compared to the world, because female survives under the influence of male dominated class. ${ }^{24}$ Eagly, Wood, and Diekman have also highlighted that gender roles which emerge from the activities assigned to each sex places men and women in their stereotypical images. Shastri, A says that gender discrimination starts at the birth of the child, because the male child birth is celebrated, whereas the female child birth is considered as a burden. Although it is the twenty first century, but many people give the glimpses of such thoughts, so this type of issues are either promoting the gender issues, or creating hurdles in national as well as social 
development. ${ }^{25}$ It is stated by the Kouvo that history is witness to the portrayal of women's secondary position against the men in the world and they are also either deprived from the fundamental basic legal rights or lacking the independency of selfdirected and autonomous personalities. ${ }^{26}$ It has been done very noteworthy research in Nigeria in gender issues and feminine injustice under Critical Discourse Analysis swarm. There, it is explored the linguistic subtlety of gender representation in English textbooks and special focus is given to expose the power relations ideological stance in syntax structure, reference system and schematic regulation. It is discovered in the study that there is visible gender conditioning in the sentences and paragraphs of textbooks and it is a source for saddening the concepts and intentions among female gender. These gender conditioning systems are maintaining the power ideologies of socially privileged male gender in the shadow of nation building. ${ }^{27}$ Babatunde and Osuolale-Ajayi also analyzed randomly few opted drink and telecommunication advertisements in Punch newspapers for the linguistics and nonlinguistic stereotypes of women and it was highlighted that women were given out the negative profile in advertising stance as well as they were also shown negative stereotyped. ${ }^{28}$ Lazer explains the patriarchal social order in CDA perspectives which systematizes the male member as an advantageous, liberal and privileged individual and female as a dependent, excluded and disadvantageous type of entity in the social group order. ${ }^{29}$ There is another linguistic and pictorial research ${ }^{30}$ which evaluates the empowerment and selfrepresentation of women. It is exposed that women are self-assertive and they are victimized by the hegemonic agenda. It is also found out there that agency of women is frivolous and they are playing the role of pacification. Equal Opportunity Commission Hong Kong (2008) states that it is a usual practice in Hong Kong to objectify the females in media which directs to misrepresent the standard of aestheticism and selfrespect in women and it also guides towards womanish disappointment finally. According to the Malik ${ }^{31}$ in Pakistan, there are few significant aspects which affect the circumstances for professional women, like religion, tradition, culture and society. He states that constant domestic needs of the ladies force them to work for economic issues in the limited employment options, minimum earnings, and unsuitable working circumstances, as competed with the opposite sex. In the Pakistani society, the women experience asymmetrical power gender relations, wrapped in the unequal and discriminated traditional values, under domestic domains as well as market spheres. ${ }^{2}$

\section{Significance of Research:}

The significance of this research lies in the fact that in Pakistan, sexual abuse and feminine injustice are increasing day by day and these issues enjoy central discussion of the media, but no one has highlighted the teachings of Quran and ideological manipulation of the media and powerful people, wrapped in their collusive stance. So, in this way it is a new finding in the research domain, which will give a new dimension to our experience and thoughts as the persuasiveness is very deep rooted. The significance of the research is also very clear because in Islamic ideologies and 
teachings the status of women is very unique, Islam either gives very powerful stress on the rights of feminine strata or also recommends very strong law and order policies for the punishment in case of any violation. The importance of this research is also very high as the very weak stratum of the society is used for the promotion of fake ideology and manipulation of everlasting Islamic ideology. The present research also gives the glimpses of habitual power abuse in language by the powerful people in the light of Critical Discourse Analysis.

\section{Research Methodology:}

This research study was carried out using the press statements, images, and columns published in the most widely read newspapers in Pakistan, by the different social class of the society, i.e., both in English and Urdu language, namely the Dawn and Express; with the reference to the brutal and savage sexual abuse and rape of Zainab. This violation has been emphasized in the light of Quranic teachings. The statements were taken during the week, after the happening of the brutal episode, when the journalists, politicians and other powerful people were discussing the matter in print media, i.e., from 8 January 2018 to 14 January 2018. The sample is selected, because a set of fake ideological assumptions was looked there, wrapped in the agenda of the gender issues and feminine injustice. Keeping in view and analyzing the basic agenda of the research, Van Dijk's Critical Discourse Analysis model was selected as tool for the analysis of text. ${ }^{2}$ The given model either has the best understanding of the present language use, or it is not only helpful to reveal the manipulative power of the media, politicians and journalists, furthermore it can also scrutinize the power issues and social problems attached with gender issues and feminine injustice in the media discourse. The framework of Van Dijk ${ }^{2}$ is applied for the analytical findings and the analysis is carried out according to the model which indicates how ideological processes may be created in different type of the texts. But for maintenance of the intensive interest among the readers and according to the hypothesis and data, only the most relevant points are selected for discussion. Basically, in this research, qualitative research paradigms are used in the critical inquiry for two basic purposes; the justification for special linguistics choice rooted in the stretches of discourse, and maintenance of power and hegemonic ideological stance in society surrounded by the textual identity. ${ }^{32}$ Furthermore qualitative research approach allows better and more in depth understanding of the collected data. The criticism also works on qualitative approach in gender role. ${ }^{23}$ The sample technique in the present research is non probability purposive sampling because only those statements and columns have been chosen for the study, which are related to the Zainab's episode.

\section{Research Questions:}

1 Is there any dominated and hegemonic agenda in Press Statements for ideological exploitation wrapped in the gender issues and feminine injustice?

2 Is there any manipulation or fake ideological assumptions for hidden motives in Print Media statements, pictures and columns? 
3 Is there any diversion from Islamic Ideology in Pakistani Press statements?

\section{Data Analysis:}

Van Dijk ${ }^{33}$ says that social power is based on privileged access to socially valued resources, similarly in the selected discourse, the privileged are struggling for an excess towards the socially valued resources and it is seen very evidently in the pictures, columns and statements, because there is not any vagueness in the authoritative domination of the print media, journalists and legal authorities against gender issues and feminine injustice. In this sense, powerful stratum of the society, the media and journalists, are trying to limit the freedom of actions in the social domain of incidents. Because by pasting the pictures of Zainab's funeral prayer and journey towards the final destination (grave) in both selected newspapers on 11-01-2018; media and journalists are observed by giving message to the public that there is lot of protest against gender issue and feminine injustice and public has taken a serious action against this savage and brutal episode of rape. But opposite to this van Dijk ${ }^{33}$ says that powerful people can also influence the minds of the society with the creation of powerful discourse, in this sense they are endeavoring to suppress the public emotional reaction and minimizing the incitement of people to rise in the shape of revolution against the present gender issue and feminine injustice due to this brutal rape. Van Dijk ${ }^{33}$ further says that there are many complexities and subtleties in the power relations, and CDA precisely considers and highlights the issues like power abuse. These issues are breaches of law, principles of democracy, equality and justice who wield power. In the selected discourse there are the glimpses of the power abuse for example on the day of Zainab's funeral prayer, the policemen are shooting directly to the people who are involved in the protest and they also have murdered two citizens. Such kind of power is termed as a dominance which is observable in the given discourse because the dominance is not only pressing the protest against gender issues and feminine injustice but also it has become the cause of two murders which is strictly prohibited in Islam. Moreover, Herman and Chomsky ${ }^{34}$ have said that the purpose of dominant discourse is to produce harmony, consent and legitimating. So, in the selected discourse, these tricks are also visible. According to Hall ${ }^{14}$ exercise of influence over dominated people in such ways that the dominated accept the dominance and work in the interest of powerful people, without their own free will, is known s hegemony. Similarly, it is said by Asif Ali Zardari (PPP Co Chairman) and Pervaiz Khattak (CM KPK) on 11 January 2018 in

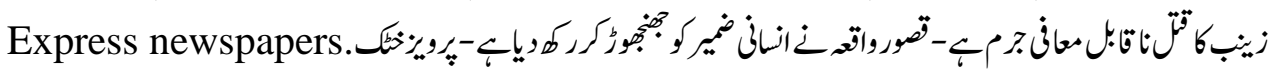

Similarly, there are few other statements, Protest continues on second day: Tahreek-i-Labbaik chief leads funeral prayer. Agitators in Kasur turn on PML-N lawmakers -

So, the hegemonic agenda of the powerful people is visible in the light of above statements because the social power in the groups not only is produced by the individuals but also is either maintained and tolerated by the powerful groups in the 
society e.g., permitted by the courts, sanctioned by the laws, imposed by the police or ideologically replicated and reproduced by the media. This powerful stratum is known as hierarchy of the power and this hierarchy is associated with decision making, management process, and power production. Van Dijk ${ }^{33}$ has said that immediate, serious and pressing issues are discussed in the theory of critical discourse analysis and it also develops more identifiable support against the hegemony and inequality. Van Dijk ${ }^{35}$ has said that roles, self-references, and identity (such as agency) are signaled with political pronouns, and there is polarization in groups and opposition, in the selected discourse, there are the visible glimpses of the actor description and they (Politicians and Journalists) are trying to present themselves in positive ways and others (political opponents and public) in the negative ways. For example,

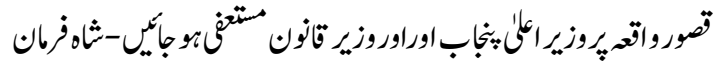

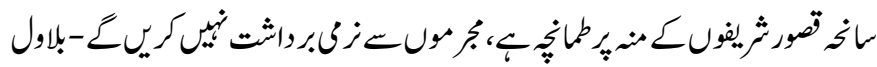

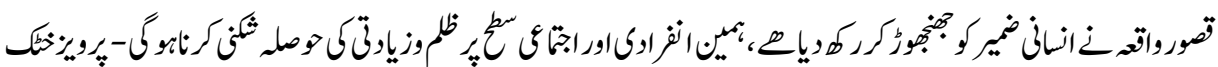

\section{Zainab's murder sparks uproar across the country. CJ initiates suomatu action.}

In the light of above statements, it is visible that there is description of the actors in the discourse, and positive self-representation for us (who are giving statements) and negative representation for others (government) can be seen. In the given statement there is an ambiguous agenda wrapped manipulatively for some hidden motives. Van Dijk $^{33}$ suggests dominance and control as a powerful excess for communication in different social settings (p. 254). Similarly in the selected discourse the actors are trying to produce control and dominance, in order to prevent adverse situation. They (actors) are determined to create the peaceful and harmonic circumstance by blaming their opponents and showing sympathetic attitude and deep supportive feelings for the victim and her family. The power and dominated level of various social groups can be measured by the control over discourse. Similarly, the speakers of selected discourse have full awareness about this fact and they are trying to cover up maximum people at the time of the brutal and savage rape. It is also known by them that these newspapers reports will be studied by maximum people in the country because by controlling the text, context and more people, they are connected with more authority and dominance ${ }^{33}$. Van Dijk ${ }^{37}$ says that it is very necessary to examine the manipulative stance in the discourse and it can be judged easily from the social environment. Thus, in the light of this argument, in this research, the social environment seems manipulative because there is very hyperbolic stance of the powerful peoples. Van Dijk ${ }^{34}$ has further said that hyperboles are helpful in the enhancement and exaggeration of the meanings and these are known as semantic rhetorical devices. So, various glimpse of hyperbolic stance can be seen in the light of selected data, and few of them are here as under.

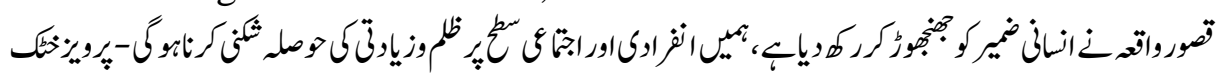




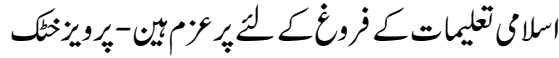

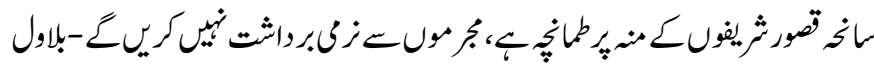

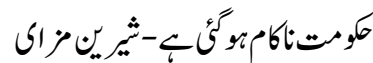

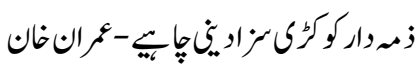

Furthermore, such kinds of approaches are instrumental towards positive selfrepresentation and negative representation of others. It also highlights the good and bad deeds among us and them accordingly. This practice is only possible through hyperbolic technique, because power and domination always work under the shadows of persuasion, and essentially mind is controlled by the social actors. For the application of this control the social actors always try to fulfill the social criteria and psychological implications. The social actors adopt these strategies for the termination of gender differences and social polarization, as their special motives can be achieved e. $g$ existence of difference among the poor and rich and they also try to influence the demarcation between authoritative and dominated. With the development of such tendencies, they struggled to bridge over the gape of dissimilarities for the sake of their own manipulated stance. Such kind of manipulation becomes the cause of social domination and power reproduction in the daily life.

In the selected discourse, there are very clear and justified glances of ironic situation, because politicians like Bilawal (Pakistan People's Party Chairman) and Sheerain Mazzari (the senior party leader from Pakistan Tahreek e Insaf) have blamed the present government for the brutal rape. Furthermore, Bilawal is manipulating the

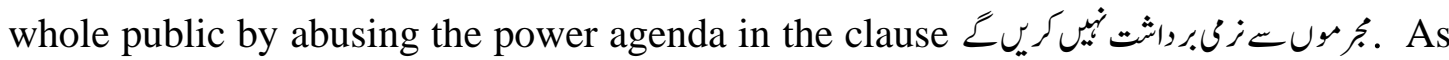
it is said by Van Dijk $\mathrm{k}^{34}$ that accusation serves very effectively for ironic purposes when it is said directly and it can be seen in the above-mentioned statements as well. So, the politicians are not only accusing the government directly and putting all the responsibility of the brutal and savage rape on the shoulders of Pakistan Muslim League (N) which is working in the government at the time of rape, but also trying to promote their politics for upcoming elections with the help of gender issue and feminine injustice. The politicians neither say any single word for compensation of gender issue and feminine injustice, nor demand any is made by them to restrict these flaws.

In addition to this, Chief Minister Punjab Mian Shahbaz Shareef meets to innocent girl's father for condolence and shows very deep kindness for the girl and her family. His style looks very sympathetic. Apparently, meanings are justifying that government is very serious and will take effective steps for the restrictions of such kind brutal and savage incidents. In Karachi, the young deaf and mute students did not remain behind and protested against gender issue and feminine injustice outside Karachi press club, likewise they tried to condemn the episode. They also raised the voice against gender issues and feminine injustice after this brutal rape. 
Likewise, there is ambiguity and equivocal stance in the rallies, protest, and marching because in all these sort of practices, single name of the victimized personality (Zainab) is referred for the creation of vagueness and ambiguity in the whole scenario, and it also guides towards the denial of respect and hate for female strata in gender issues and feminine injustice domain which one should give to the female gender in Islamic society. The single word of the name (Zainab) also provides negative connotation in the investigations of episode and it can be a way towards the use of diplomatic tactics by the enemies of Islam. It is also possible; all the organizations and activists may be utilizing the pressure and negotiation of this episode to promote their hidden agenda for the achievement of their own motives. In addition to this, there are few words used for victims, which justify the helplessness and lack of the social power on the part of her family and these words also throw the glimpses of very long social distance between the speakers in press statements and victimized personality and her family. For example، نتم، كمث، "مصوم

There is more trustworthiness and reliability on the part of the speakers when they share their knowledge and opinions in the light of reliable sources, especially if there is confusion and mystification and reality is not clear, it is known as evidentiality. Hence in the selected discourse there is such agenda on the part journalists and politicians to prove the legitimacy of their opinions. For instance, in Album No. 1, there is visible sign of evidentiality, and furthermore, it is also used hyperbolic stance and exaggeration which make the situation more crucial, adverse, and argumentative. The context of the study reveals that these arguments may lead the situation towards the adversity, because there was a great tussle in Kasur in those days.

Van Dijk ${ }^{34}$ has said that one of the most prominent features of discourse is, what is unsaid, but it implicitly exists in the shape of presuppositions, implications and implicatures. Similarly, there are several points which are implicated and presupposed. There is another interesting thing that pragmatic implicatures and presuppositions are used in the press statements in the form of positive self-presentation and negative others presentation. These two pragmatics theories convey much more then it is said.

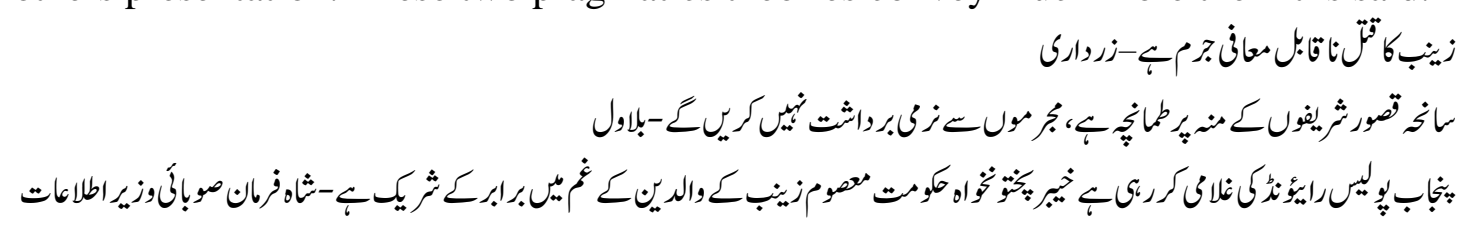

According to the above-mentioned statements of Zardari, it can be presupposed that in this country such kind of murders are always forgiven by the law and order, similarly in the statements given by Bilawal, it can also be presupposed that in Pakistan, such criminals of rape and murder are obliged by the relaxation against laws. There are various implied meanings that are easily inferable from the statements. For example, according to the Khyber Pakhtunkhwa information minister statement, it can be implied that police system in Pakistan is not working at the parameters of the law and is being 
abused by the government.

\section{Findings and Discussion:}

Initially in the selected discourse, there is a power abuse, and powerful people in Pakistan are using discursive strategies for the promotion of hidden ideologies wrapped in the cloth of collusive stance to achieve their own motives. They have used the gender issues and feminine injustice as a working tool towards the attainment of their own end by manipulating the public simultaneously they are violating from teachings of Quran. In this sense they are trying materialistically to minimize the chances to erupt the revolution in the back ground of savage, gruesome rape and murder against constitution and concerned authorities. They are using the fake agenda instead of Quranic verses for the punishment of victim. They are trying for the minimization of agitation, hostility and riots, regardless of gender issues and feminine injustice, which has consequently caused the sexual abuse and murder of innocent girl.

Secondly Pakistan is an Islamic country, which has been achieved at the name of Islam and such kind of activities in discourse may cause specific identity for speakers and nation in the sense that this press media discourse is the causing the situations of pornography. Furthermore, in the context of brutal rape it can lead towards psychological complication among female strata. Simultaneously it is a violation of Quranic teachings.

Thirdly according to all statements, pictures and columns of print media in the selected discourse, there is not even a single statement of politician, journalists, and judiciary that may indicate the steps towards the enforcement of Islamic law and teachings of Quran. The senders of discourse are just looking busy for the accomplishment of manipulative stance to meet their own end as following.

A: Politicians have used the episode of gender issue and feminine injustice as a political war and they are exploiting the teachings of Quran. An evaluation of selected discourse in Dawn and Express newspapers on the gender issues and feminine injustice manifests that there is manipulation that is having underlying political and ideological interest wrapped in the assumptions of condolence and ideological political victorious glances are presupposed in the linguistics constructions. There is a language exploitation grounded in power ideology as well as the neutralization of the episodic sufferings is seen in the lexico-grammatical options. It is also noted that there is visibility of ideological deconstruction in the use of hegemony, power abuse and dominance. The unequal and oppressive stance might be related towards the personal interest.

B: Journalists are trying to induce hallucination in community because in the light of research questions, there is revealed in the study that unequal stance in gender issue and feminine injustice is wrapped in power abuse. The guardianship of the law has failed to restrict the gender issues and feminine injustice in Pakistan and there is inherited privilege of male counterpart in the country against the teachings of Quran. It is observed in the research that such kinds of episode are snatching the opportunities from the female strata to be independent and liberal because the social system has been handicapped due to injustice and exploitation. 
C: Political Government has ordered for inquiry and is apologizing to the innocent girl's parents, but there is hardly any solid step for enforcement of Islamic law as well as need for social awakening in the attitude and mind set of masses in the light of Islamic teachings.

D: Although in the days of episode, it is given a special focus by print media to provide the coverage of this incident, but there is hardly any positive step of print media to restrict such episodes in the country by suggesting the Islamic law enforcement. So, there are the chances that media may be working to create the pacification in circumstances and journalists can be the supportive elements for media to induce hallucination in community.

\section{Conclusion:}

It is recommended that government and judiciary should take the solid steps for initiation and implementation of strict law and order in the light of Islamic teachings, so that these cruelties may be restricted on tumultuous basis. In this sense, the worst part of the whole scenario is that, in Pakistan so many episodes of rape and abduction have happened against ladies, but barriers are looking still impossible for these episodes. The mass media in Pakistan has hardly taken any positive step for implementation of law and discussion of gender issues and feminine injustice in legislation as a special national issue for the implementation of Islamic law and order to punish such crimes. It is also needed strongly to establish a committee for legislative matters against gender issues and feminine injustice according to Islamic teachings which should take the following steps on urgent basis.

Enforcement of Islamic law in Pakistan is very compulsory, because it is evident that we have failed to fight with and undo the structure which is creating oppression and violence in feminine injustice and gender issues. Simultaneously, it has been observed in Pakistan as well as in most of the world, peoples are never served by the laws because the assumption that basic rights are enshrined in the laws, are inalienable in postcolonial countries. Although after the freedom, most of the post-colonial states depicted themselves as guarantor of law like Pakistan yet it continued to impose the power interest and it was carried out under the shadow of formal legal procedures left behind by the colonizers. As it is observed that there are the institutions which uphold the privileges of the patriarchal domination in our homes, schools, workplaces, and religious institutions. Time and again we request the state's law and order apparatus to protect us and time and again it demonstrates that it cannot or will not. Furthermore, the power relations are reinforced by the police functionaries at local level but they are either unwilling or impotent to confront more powerful state functionaries, who are involved in the practice like enforced disappearances e.g., gender issues and feminine injustice. It brings us to the conclusion that decolonization of the law must be identified because the proliferation of legal exceptions in the contemporary period has become a fundamental issue for the world as well as country that can be solved by the Islamic law only. 
Education of Islamic teaching in masses is very compulsory to promote the awareness that such kind of activities is heinous crime in Islam. If it is not promoted the endemic abuse of power and lack of justice will leave society seething with pent up frustration and ignorance. Similarly, this mayhem may not able to condone Islamic ideology and its roots will penetrate into the society more rapidly, until and unless changing of mindset with Islamic teachings is not promoted.

Solid steps for the solution of gender issues and feminine injustice should be the initial priority. In the society, the heinous crimes like gender issues and feminine injustice provoke acute trepidation among the community and in Pakistan; criminal investigations are not standardized to lead towards timely prosecutions. The traumatized cases of gender issues and feminine injustice are not looked after by the law enforcement authorities seriously and law enforcement's lackadaisical attitude has developed out of the knowledge that there will be absolutely no repercussions for its failure to properly compile and analyze the evidences against crimes. The idea that law is functioning as instrument for the liberation of ordinary people, is relatively becoming a novel and such kinds of ferocious crimes against feminine injustice and gender issues are beyond the imagination over stable mind. Finally, the state must form a policy to curb the roots of such inhuman crimes by producing the remedies. This is not first time that there is subjected an innocent soul for brutality but many cases have been reported in last few years. The authorities are still silent. Now, the government will have to change its priorities and attitude and serious actions and requisite political will are needed to stop these violence crimes in gender issues and feminine injustice.

\section{References:}

${ }^{1}$ Surat Al-Nisa: 124

${ }^{2}$ Van Dijk, T. A. (1997). Discourse as structure and process of discourse studies: A multidisciplinary introduction. Volume I. SAGE Publications, London

${ }^{3}$ Pokharel, Samidha 2008.Gender discrimination: Women perspectives, Nepalese Journal of Development and Rural Studies,5(2):80-87.

${ }^{4}$ Surat At-Tawabah (Repentence)

${ }^{5}$ Bastola, Garima (2007) Gender inequality starts before birth, The Kathmandu Post: National daily newspaper, VolXV (69) (April 27):

${ }^{6}$ Amorós, C., 1990. Violenciacontralasmujeres y pactospatriarcales. In: V. M. D'Angelo and C. Sánchez,edas. 1990. Violenciaysociedadpatriarchal. Madrid: Pablo Iglesias. Pp.1-15.

${ }^{7}$ Patowary H. (2014) Journal of education and social policy.

${ }^{8}$ Gee, J. P. (2014). An introduction to discourse analysis: Theory and method ( $4^{\text {th }}$ edition). Oxford, England: Routledge.

${ }^{9}$ Surat Al-Noor

${ }^{10}$ Surat Al- Ghafir (The Forgiver)

${ }^{11}$ Brown, G. (1983). Discourse analysis. Cambridge, UK: Cambridge University Press.

${ }^{12}$ Van Dijk, T.A. (2001). Multidisciplinary CDA. In Wodak, R \& M. Meyer. Methods of critical discourse analysis. SAGE Publications, Great Britain.

${ }^{13}$ Carvalho (2008) "Media discourse and society: Rethinking the framework of CDA",Journalism Studies, 9 (2). 
${ }^{14}$ Hall, Stuart (ed) (1997). Representation: Cultural representations and signifying practices. London: SAGE, Open University Press.

${ }^{15}$ Foucault, Michel (1972b). Discourse on language. In Michel Foucault, The archaeology of knowledge (pp.215-238). New York: Pantheon.

${ }^{16}$ Fairclough, N. (2015). Language and power. Longman, UK.

${ }^{17}$ Van Dijk, T.A. (1998) Ideology: A Multidisciplinary Approach. London: Sage.

${ }^{18}$ Halliday, Michael Language, Context and Text: Aspects of Language in a Social Semiotic Perspective. London: Oxford UP. 1985. Print.

${ }^{19}$ VanDijk, T. A. 1991. Racism and the press. London: Routledge.

${ }^{20}$ Toolan, M. J. (2001). Narrative: a critical linguistic introduction. New York: Routledge.

${ }^{21}$ Courtney, Alice E. and Sarah Wernick Lockeretz (1971), “A Woman's Place: An Analysis of the Roles Portrayed by Women in Magazine Advertisements" Journal of Marketing Research, 8 (February): 92-5

${ }^{22}$ Furnham, A., \&Bitar, N. (1993). The stereotyped portrayal of men and women in British television advertisements. Sex Roles, 29, 297-310.

${ }^{23}$ Cheng, K. \& Leung, L. (2014) Reinforcing Gender Stereotypes: A Critical Discourse Analysis of Health-Related PSAs in Hong Kong: American International Journal of Social Science.

${ }^{24}$ Fung, A. (2000). Feminist philosophy and the cultural representation in Asian context. Gazette, 62(2), 153-165

${ }^{25}$ Shastri, A. (2014). Gender Inequality and Women Discrimination IOSR Journal of Humanities and Social Science Paper.

${ }^{26}$ Kouvo, S. (2008). A "quick and dirty" approach to women's emancipation and human rights? Feminist Legal Studies, 16(1), 37-46.

${ }^{27}$ Ibrahim, M. (2015). Gender sentiments in Nigerian primary English textbooks: A critical analysis. Journal of the Nigeria English Studies Association Vol. 17, 84-93.

${ }^{28}$ Babatunde and Osuolale-Ajayi (2015) A Non-Verbal Analysis of Female-based Advertisements in Nigeria's Punch newspaper Nigeria English Studies Association, Obafemi Awolowo University, Ile-Ife 94-107

${ }^{29}$ Lazar, Michelle M. (2005). Performing the State Fatherhood: The Remarking of Hegemony. In Michelle Lazar (ed). Feminist Critical Discourse Analysis: Gender, power, Ideology in Discourse. London: Palgrave Macmillan,139-63

${ }^{30}$ Daniel, I. O. (2011). Ideology, power and pictures of women. Journal of the Nigerian English Studies Association (JNESA) 14:2, 112-131

${ }^{31}$ Malik, A. (2009). The Status of Working Women in Pakistan.

${ }^{32}$ Fairclough, N. (1999). Critical discourse analysis: The critical study of language. United Kingdom: Longman

${ }^{33}$ Van Dijk, T. A. (1993b). Principles of critical discourse analysis. Discourse and Society 4(2), 249-83.

${ }^{34}$ Herman, E.S. and Chomsky,N.(1958) Manufacturing Consent-The Political Economy of Mass Media. New York: Pantheon Books.

${ }^{35}$ Van Dijk, T. A. (2000). Parliamentary Debates Issues in six European states (pp. 45-78), Klagenfurt, Austria:DravaVerlag

${ }^{36}$ VanDijk, T. A. (2001). Critical discourse analysis. In D. Tannen, D. Schiffrin\& H. Hamilton (Eds.), Hand book of Discourse Analysis (pp. 352 -371). Oxford Blackwell. 